\title{
INVESTMENT, INFORMATION, AND PROMISSORY LIABILITY
}

\section{JASON SCOTT JOHNSTON ${ }^{\dagger}$}

In Contracts Without Consent: Exploring a New Basis for Contractual Liability, ${ }^{1}$ Omri Ben-Shahar, a talented and creative economic analyst of law, advocates a principle-which he calls the "no-retraction" principle ${ }^{2}$ - that is so at odds with the existing structure of the common law of contracts $^{3}$ as to basically turn contract law upside down. BenShahar's no-retraction principle would radically alter the line between agreement and no agreement, between liability for unkept promises or assurances and no liability for such unkept promises or assurances. Indeed, under a no-retraction regime, there would be no line between agreement and no agreement, and contractual liability could exist even in the absence of any communication (or what Ben-Shahar calls a "proposal") ${ }^{4}$ at all. Transactions could be forced upon parties who want nothing to do with them-either because they've walked away from failed negotiations or because they were never in any negotiations to begin with-but only on the terms that were or would have been demanded by the unwilling party. By incurring reliance expenditures early in a contractual negotiation (or, apparently, before a negotiation had even begun), a relying party could hold the other negotiating party liable for those reliance expenses, regardless of

\footnotetext{
${ }^{\dagger}$ Robert G. Fuller, Jr. Professor of Law and Director, Program on Law and the Environment, University of Pennsylvania Law School.

${ }^{1}$ Omri Ben-Shahar, Contracts Without Consent Exploring a New Basis for Contractual Liability, 152 U. PA. L. REV. 1829 (2004). ciple).

${ }^{2}$ See id. at 1838-53 (explaining the reasoning behind and the benefits of this prin-

Inasmuch as "[t]he central tenet of the civil law . . . is that promissory estoppel does not exist," David V. Snyder, Comparative Law in Action: Promissory Estoppel, the Civil Law, and the Mixed Jurisdiction, 15 ARIz. J. INT'L \& COMP. L. 695, 703 (1998), the noretraction regime is even more baldly inconsistent with the civil law basis for promissory liability. See also JOHN P. DAWSON, GIFTS AND PROMISES: CONTINENTAL AND AMERICAN LAW COMPARED 88-90, 188-91 (1980) (discussing the failure of either French or German courts to attach independent significance to detrimental reliance as a basis for promissory enforcement).

${ }^{4}$ Ben-Shahar, supra note 1, at 1831 (referring to "precontractual representations of ... proposed terms" as "proposal[s]").
} 
whether those expenses were incurred in reliance upon a promise. ${ }^{5}$ Ben-Shahar defends his proposal both as representing "a conceptual advance" ${ }^{, 6}$ and as creating superior economic incentives relative to the existing American common law doctrinal regime. ${ }^{7}$ He says that the no-retraction regime is a conceptual advance because it is "a 'natural' legal platform for tracking the progress of [contractual] negotiations" that "provides a more flexible set of tools for transforming the understandings between parties into legal obligations." ${ }^{8}$ He says that the noretraction regime is superior on efficiency grounds to the existing doctrinal regime because it would encourage precontractual reliance where it is socially desirable to do so, while at the same time avoiding any chilling effect on the incentive to enter and make proposals in negotiations. ${ }^{9}$

In this brief Commentary, I take Ben-Shahar's no-retraction proposal as an opportunity to compare and contrast two alternative economic approaches to thinking about the question of what sort of statements or actions ought to trigger contractual liability. Although this question is often referred to as the issue of "precontractual liability," ${ }^{10}$ it is in fact much more general, involving the fundamental question of why it is ever economically desirable to attach legal liability to a party's failure to transact. I argue that, while Ben-Shahar's proposal may indeed encourage efficient early reliance, its likely inefficiency in discouraging negotiations from even beginning and in encouraging inefficient and unconsented transactions far outweighs its potential efficiency benefits. Thus, Ben-Shahar's no-retraction regime is decidedly inferior on efficiency grounds to the current doctrinal approach.

Along the way, I hope to persuade the reader of a much more general point. Ben-Shahar's conceptually confusing, practically impossible, and instrumentally unwise no-retraction idea is not the result

\footnotetext{
${ }^{5}$ See, e.g., id. at 1845 (" $[\mathrm{I}] \mathrm{n}$ situations in which parties have not completed the negotiations but merely have reached some preliminary understandings, ... the optimal remedy for retracting from the understandings and the proposal would be reliance damages.").

${ }^{6}$ Id. at 1847

${ }^{7}$ Id.

${ }^{8} \mathrm{Id}$.

${ }^{9}$ See id. at 1847-53 (explaining the "[t]he [e]fficiency of the $[\mathrm{n}] \mathrm{o}-[\mathrm{r}]$ etraction $[\mathrm{r}] \mathrm{e}-$ gime").

${ }^{10}$ The best general discussion of "precontractual liability" remains E. Allan Farnsworth, Precontractual Liability and Preliminary Agreements: Fair Dealing and Failed Negotiations, 87 COLUM. L. REV. 217 (1987).
} 
of bad economics, but of having taken a very rigorous and sound economic model far too seriously and immodestly. That model-known either as "the reliance model" (in law and economics) or the "optimal investment model" (in economics) - thinks that the fundamental problem solved by contractual law is to get the correct incentives for people to make investments that increase the value of contractual transactions. ${ }^{11}$ It worries that, if the law doesn't give people a right to recover their reliance investments when the transaction doesn't occur because the other party backs out, then they will have an inadequate incentive to make such investments. Providing them an automatic right to recover fully compensatory damages in such an event, however, will give people no incentive to economize on reliance investments.

While this may seem to suggest that all that we've gotten from the model of reliance is the revelation of yet another doctrinal dilemma, as I explain in more detail in the first Part, the model of reliance also suggests a solution. The problem with Ben-Shahar's no-retraction proposal lies not with the model of reliance that it is based upon. The problem with Ben Shahar's proposal is that it forgets that there is a huge difference between finding that a particular liability regime can fix a particular, limited problem identified by such a formal (that is, mathematical) model and advocating that regime as generally superior to the existing doctrinal system. The problem is that, like any model, the model of reliance is limited and illuminates only part of the problem posed by the question of what sort of statements or actions ought to trigger contractual liability. It is surely true both that contract remedies do cut the risk to people of investing in the cooperative ventures that we call contracts and that it sometimes may be desirable for people to begin to invest earlier, rather than later, in such ventures. Ben-Shahar's no-retraction regime, like other proposals devised by economists, ${ }^{12}$ does cut the risk of investing to increase the value of a contract and then being held up by a party who refuses to bear her fair share of that investment. But along the way, it creates an incentive for people to incur early reliance expenses solely in order to foist highly inefficient contracts upon other people, people with

${ }^{11}$ For a lucid discussion of this point, see Aaron S. Edlin, Breach Remedies, in 1 THE New Palgrave Dictionary of Economics and the LaW 174 (Peter Newman ed., 1998).

${ }^{12}$ For a description of some of the alternative solutions proposed, see Eric A. Posner, Economic Analysis of Contract Law After Three Decades: Success or Failure?, 112 YALE L.J. 829, 856-59 (2003). 
whom they may not even have been bargaining. It thus undermines a basic economic underpinning of contract law: the promotion of efficient, net-value-maximizing exchange.

Ben-Shahar's no-retraction regime also mistakes the reliance problem, which clearly is part of the problem raised by precontractual liability cases, for the whole problem. The question of when contractual liability ought to attach to promissory statements is not only about how people invest (or don't) to increase the value of cooperation. It is also about the incentives people have in attempting to discern whether cooperation is mutually beneficial in the first place. Precontractual liability effects incentives in dealmaking, incentives not regarding reliance investments that increase the size of the pie, but incentives to invest in order to acquire and transmit information about the likelihood that there is any pie to split in the first place. The model of reliance does not capture those incentives. It was not designed to do so.

An alternative model, which I developed some years ago, ${ }^{13}$ does address those incentives and, in so doing, tends to indicate that the existing doctrinal structure accords quite closely with what an informationally efficient regime would look like. ${ }^{14}$ In this Commentary, after discussing the analytical development of the reliance model and Ben-Shahar's application of it in devising his no-retraction regime, I review my alternative model and its conclusions. I do so not to prove that my approach—which may be called simply "the bargaining model"-is "better" than Ben Shahar's reliance model. Neither model captures the whole story. By comparing these approaches, one sees that they are complementary, not competitive. More importantly, one sees also that any proposal, such as Ben-Shahar's, that immodestly asks a model to do more than it was ever designed to do is bound to be wrong.

\section{The Model of RELIANCE IN THE ECONOMIC ANALYSIS OF CONTRACT LAW: ITS REMEDIAL BEGINNINGS}

The model of reliance had its beginnings, as did the economic analysis of contract law more generally, in the analysis of contract

${ }^{13}$ Jason Scott Johnston, Communication and Courtship: Cheap Talk Economics and the Law of Contract Formation, 85 VA. L. REV. 385 (1999).

${ }^{14} I d$. at $491-96$. 
remedies. $^{15}$ These beginnings may be illustrated with a simple buyerseller example. As every contracts student learns, when the seller's opportunity cost is less than the valuation that the buyer places on a good or service, then joint performance-the seller's production and delivery of the good and the buyer's payment of the promised pricemakes each party better off than she would be without such a deal and generates a net increase in social value.

In a more complicated example, a swimwear manufacturer that has built up brand loyalty may wish to extend the value of that intangible asset to suncare products. But this swimwear company does not have any experience or expertise in making such products and hence is interested in contracting with a company that does have such expertise. Joint performance in this example means that the swimwear company will not only license its trade name for use on the new suncare products, but will also cooperate in marketing and promoting the new suncare line. The suncare company, for its part, must produce a suncare product and packaging that will succeed on the market. The gain from successful cooperation is a mutually profitable new product line.

In each of these examples, for gains from exchange to be realized, one or more of the parties may need to incur costs that may not be recoverable unless the two contracting parties actually cooperate by performing. In the first example, the seller may be producing goods tailored to the particular buyer's needs and so will recover only a portion of the cost of production by reselling if this particular buyer fails to perform. In the second example, at least some of the money spent by the swimwear company in promoting a new line of suncare products will be lost if the particular line being promoted is never produced and brought to market. Similarly, some fraction of the money spent by the suncare company in designing and testing a new suncare product will be lost if the swimwear company backs out of the deal and refuses to license the use of its name or to help in marketing and promoting the new product.

${ }^{15}$ See L. L. Fuller \& William R. Perdue, Jr., The Reliance Interest in Contract Damages (pts. 1-2), 46 YALE L.J. 52, 373 (1936-1937), for an early exploration of the concept of reliance in contract theory. For a further discussion of the influence of Lon Fuller and William Perdue's perspective on law and economics in contract theory, see Avery Katz, Reflections on Fuller and Perdue's The Reliance Interest in Contract Damages: A Positive Economic Framework, 21 U. MiCH. J.L. REFORM 541 (1988). Eric Posner also provides a useful historical survey of the economic analysis of contract theory in Posner, supra note 12 . 
In the legal literature on contracts, such costs are referred to as the parties' "reliance expenditures." A main concern of economic analysts of contract law has been whether contract law default remedies create an incentive for efficient levels of such reliance, where the efficient level of reliance is defined as that which maximizes the expected net social value of exchange. ${ }^{17}$ Here, "expected" means the average value of exchange, given the known uncertainty surrounding performance. ${ }^{18}$ "Efficient reliance" is reliance that maximizes the expected net value of exchange, where the net value is discounted by the known probability of non-performance. ${ }^{19}$ If, for instance, an owner knows that bad weather or a labor strike may prevent her builder from completing a restaurant addition on time, then even though she will increase her profits by making early reliance expenditures in hiring new staff and buying new equipment that allow her to open the new addition if it is completed on the promised date, the owner should factor in the probability of late completion before relying in this way. On this calculus, if the owner expects additional profits of $\$ 200$ from timely (versus late) completion by the contractor, then she will efficiently invest the $\$ 100$ in early reliance necessary to realize those additional profits if and only if the probability of timely completion by the contractor is bigger than $0.5 .^{20}$

An early and important insight from the economic analysis of contract remedies was that a damage measure that fully compensates the victim of contract breach will cause such a victim to incur inefficiently high reliance expenses. ${ }^{21}$ If the owner in the above example is awarded her full, expectation-based measure of damages when the contractor is indeed late in finishing the addition, then the owner will end up with a net return of $\$ 100$ regardless of whether or not the contractor finishes on time. Because she is, in effect, fully insured against breach, the owner is better off making the reliance investment than

${ }^{16}$ This notion of the reliance interest in contract law dates at least from Fuller \& Perdue, supra note 15 , pt. 1.

${ }^{17}$ For a discussion of the concept of "efficient reliance," see Richard Craswell, Offer, Acceptance, and Efficient Reliance, 48 STAN. L. REV. 481, 489-94 (1996).

${ }^{18} I d$. at $486-87$.

${ }^{19} I d$. at $490-91$.

${ }^{20}$ This example is drawn from and developed in much more detail in ROBERT COOTER \& THOMAS ULEN, LAW AND ECONOMICS 248-58 (3d ed. 2000).

${ }^{21}$ This result was first formally established by Steven Shavell, Damage Measures for Breach of Contract, 11 BELLJ. ECON. 466, 472 (1980). 
not, regardless of the probability of breach. ${ }^{22}$ The owner will therefore disregard the probability of breach in making the reliance investment and, in particular, will make the investment even when the probability of breach is too high (above 0.5 in this example).

In more technical, economic language, a legal rule that requires the breaching party to make the breach victim whole regardless of the reasonableness of the victim's reliance expenditures raises a moral hazard problem, inducing too much reliance by the victim. While economists have generalized the term "moral hazard" to refer to any situation in which contracting terms effect incentives for unobserved actions, ${ }^{23}$ the term originated with insurance contracts, ${ }^{24}$ where full insurance against a particular loss may cut the insured's incentive to take care to reduce the likelihood that the loss occurs and/or the amount of the loss. Insurers have known about the moral hazard problem for a long time. Unsurprisingly, they have developed wellknown contractual solutions, such as deductibles (whose primary effect is to strengthen the insured's incentive to prevent the loss) and coinsurance (whose primary effect is to strengthen the insured's incentive to lessen the magnitude of the loss). Contract law does not, by contrast, seem to have found a way to deal with the moral hazard problem induced by fully compensatory damages for breach. Cutting a breach victim's damage award by setting damages equal only to her reasonable (that is, efficient) reliance expenditures does eliminate the moral hazard problem, but only by creating another moral hazard problem in the form of too great an incentive for contract breach by the other party. ${ }^{25}$ While it is theoretically possible to design a liquidated damage measure that would optimize both the promisee's incentive to rely and the promisor's incentive to take precautions

${ }^{22}$ To more concretely illustrate this point, observe that, if the owner makes the investment, she will get $\$ 200-\$ 100=\$ 100$ regardless of whether the owner performs, since in this case the expectation-based remedy would give her the $\$ 200$ value from expected performance. If the owner does make the investment, then she will get $\$ 0$ if the contractor performs-because she is not ready to open when the addition is finished-and $\$ 100$ if the contractor fails to perform-because this was her expected profit. Thus, the owner is clearly better off making the reliance investment than not doing so.

${ }^{23}$ Andreu Mas-Colell et AL., Microeconomic Theory 478-88 (1995).

${ }^{24}$ See id. at $477 \mathrm{n} .1$ (stating that, as originally used, "moral hazard" referred to the problem "aris[ing] when an insurance company [could not] observe whether the insured exert[ed] effort to prevent a loss").

${ }^{25}$ See COOTER \& Ulen, supra note 20, at 194-96 (discussing parties' incentives to perform and breach under scenarios of low and high reliance damages). 
against breach, ${ }^{26}$ the common law has traditionally been skeptical about enforcing liquidated damage provisions. ${ }^{27}$ Instead, common law judges have indicated a great attachment to expectation damages as a "hard" default, meaning a default rule that it is difficult for the parties to vary through explicit contractual language. ${ }^{28}$

Were one convinced that the overreliance problem is a "real" problem, then this doctrinal state of affairs would be disturbing. But there is no reason to think that overreliance is a real problem. Even as a purely theoretical matter, overreliance arises only for certain kinds of reliance investments and for certain kinds of (quite simple) contracts. $^{29}$ The assumptions about contract remedies that drive the overreliance problem, moreover, are fanciful. For a whole variety of reasons-including the American rule on attorneys' fees and the inability to prove all elements of loss-expectation-based damages do not fully compensate victims of breach, ${ }^{30}$ and businesspeople decidedly prefer performance to breach. ${ }^{31}$

\section{The Model of Reliance: Its EXTEnsion to Promissory ESTOPPEL AND THE PRECONTRACTUAL LIABILITY PROBLEM}

The fact that the common law of contract has never seemed to worry about the overreliance problem thus seems to make very good economic sense. When it comes to reliance, the problem that common

${ }^{26}$ See, e.g., Robert Cooter, Unity in Tort, Contract, and Property: The Model of Precaution, 73 CAL. L. REV. 1, 11-16 (1985) (illustrating the optimal incentives that may be created through stipulating damages when contracting).

${ }^{27}$ For a discussion of the common law approach and the classic economic critique of that approach's skepticism toward liquidated damages, see Charles J. Goetz \& Robert E. Scott, Liquidated Damages, Penalties and the Just Compensation Principle: Some Notes on an Enforcement Model and a Theory of Efficient Breach, 77 COLUM. L. REv. 554 (1977).

${ }^{28}$ I refer here, again, to the skepticism with which courts still approach the enforcement of liquidated damage terms, a skepticism decried by, but nonetheless faithfully followed by, Judge Richard Posner in his opinion in Lake River Corp. v. Carborundum Co., 769 F.2d 1284, 1289-92 (7th Cir. 1985).

${ }^{29}$ This body of work is insightfully summarized and explained in Edlin, supra note 11, at 176-77.

${ }^{30}$ This point, among many others, can be found in the critique of overreliance presented by Melvin A. Eisenberg \& Brett H. McDonnell, Expectation Damages and the Theory of Overreliance, 54 HASTINGS L.J. 1335, 1357-61 (2003).

${ }^{31}$ See, e.g., Lisa Bernstein, Private Commercial Law in the Cotton Industry: Creating Cooperation Through Rules, Norms, and Institutions, 99 MiCH. L. REV. 1724, 1754-55 (2001) (citing reasons why merchants in the cotton industry prefer performance over payment for breach). 
law judges and the drafters of the Restatement (Second) of Contracts ${ }^{32}$ have sought to address is not that common law remedies are so generous as to induce overreliance, but that common law rules regarding contract formation are so formalistic that parties will often reasonably rely on a promise and yet not receive any remedy at all because they relied before a contract had been legally created-this is the problem addressed by the doctrine of promissory estoppel and section 90 of the Restatement. ${ }^{33}$ By creating a cause of action for a promisee who reasonably relied upon a promise that the promisor should have reasonably expected to induce such reliance, promissory estoppel dispenses with the traditional notion that contracts are created by mutual assent. Under traditional contract formation doctrine, contractual liability follows only if both parties should reasonably have expected to be bound. ${ }^{34}$ Under promissory estoppel, by contrast, liability depends upon the parties' shared reasonable expectation that one of them would begin to make "definite and substantial" reliance expenditures in response to the other's promise. ${ }^{35}$

There are at least three ways to rationalize promissory-estoppelbased liability. The first says that promissory estoppel really just fixes gaps in contract enforceability caused by the hyperformality of common law contract formation doctrine. On this view, the kind of situation dealt with by promissory estoppel is one in which, even though there is no consideration and/or assent to be bound, it is clear from the context that the promisor (e.g., an employer) never would have made certain promises (e.g., new employee benefits) if she didn't expect to get something of quite tangible value from the employee (e.g., enhanced, on-the-job effort). Rather than making legal enforceability of such a promise depend upon the promisee's attorney's craftiness in finding legal consideration and assent, promissory estoppel seemingly allows a much more straightforward path to recovery: establish that the employer made a promise and that the employee relied andgiven that the promise was made in the employment context-that a reasonable expectation of reliance and hence damage recovery should follow more or less automatically.

${ }^{32}$ Restatement (SECOND) OF CONTRACTS (1981).

${ }^{33}$ Id. $\$ 90$

${ }^{34}$ For a classic statement regarding the objective theory of assent, see Judge Learned Hand's opinion in Hotchkiss v. National City Bank of New York, 200 F. 287, 293 (S.D.N.Y. 1911).

35 RESTATEMENT (SECOND) OF CONTRACTS $\$ 90$ (1981). 
Courts have not agreed. In such employment benefits cases, they generally have denied recovery on promissory estoppel grounds. ${ }^{36}$ The obstacle has been that there typically is no concrete act of reliance induced by the employer's promise (e.g., where is the act of reliance by an existing employee who simply continues in her existing job after the employer promises new benefits?). More generally, finding an act of reliance and tying it to the promise may be just as formalistic an exercise as finding consideration.

I doubt that the drafters of the Restatement would have conceded this. Even if they had, they would have argued that promissory estoppel was, in any event, intended not as a modest remedy for cases of formalistic underenforcement, but as a bold and (according to Grant Gilmore $)^{37}$ revolutionary recognition of reliance itself as a basis for promissory liability. On this second justification, promissory estoppel seeks to remedy the apparent ex post injustice suffered by those who have suffered losses in reasonably relying on promises. Promissory estoppel is, this view holds, all about the prevention of injustice. However, unless it is always unjust for someone to suffer detriment in reliance upon a broken promise, the bottom-line problem is to determine just when it would be unjust to allow such detrimental reliance to go without compensation.

In comment b to section 90, the drafters of the Restatement provided some factors for courts to look at in making this determination. $^{38}$ These boil down to an inquiry into the promise that induced the reliance-was it the kind of formal, complete, and deliberate communication that should have been expected to induce reliance

${ }^{36}$ Robert E. SCOTt \& Jody S. Kraus, Contract LAW AND TheOry 185 (3d rev. ed. 2003).

${ }^{37}$ See Grant Gilmore, The Death of Contract 72 (12th prtg. 1982) (arguing that section 90 has "swallowed up the bargain principle of [section] 75" and that, under modern contract law, "the 'probability of reliance' may be a sufficient reason for enforcement without inquiring into whether or not there was any 'consideration"”).

${ }^{38}$ The comment reads:

The principle of this Section is flexible. The promisor is affected only by reliance which he does or should foresee, and enforcement must be necessary to avoid injustice. Satisfaction of the latter requirement may depend on the reasonableness of the promisee's reliance, on its definite and substantial character in relation to the remedy sought, on the formality with which the promise is made, on the extent to which the evidentiary, cautionary, deterrent and channeling functions of form are met by the commercial setting or otherwise, and on the extent to which such other policies as the enforcement of bargains and the prevention of unjust enrichment are relevant.

RESTATEMENT (SECOND) OF CONTRACTS $\$ 90 \mathrm{cmt}$. b (1981). 
and upon which one would reasonably rely? - and the reliance thereby induced-did the promisor, by inducing the reliance, really cause substantial, measurable harm? If the answer to each of these questions is "yes," then courts generally find that it would be unjust not to provide recovery on a promissory estoppel theory. ${ }^{39}$

A third justification for promissory estoppel is that it has proven to be an enormously powerful tool for recovering damages for promissory breach in circumstances in which it is quite clear that the parties have not yet reached what the common law deems a legally enforceable agreement. While there are many such circumstances, one especially important context for the application of promissory estoppel has been that of failed negotiations. In a typical failed negotiations case, the parties have been negotiating over a cooperative venture or transaction-I shall use the two interchangeably-and have made various optimistic assurances or promises to one another to the effect that the transaction would happen, but those assurances went unfulfilled because one party, the faithless suitor, walked away. The other party, the disappointed suitor, insists that the parties had a deal-a contractthat has been breached. But because any number of terms were never hammered out during the negotiations or because the parties expressly may have included language in some of the earlier negotiating

${ }^{39}$ Both Daniel A. Farber \& John H. Matheson, Beyond Promissory Estoppel: Contract Law and the "Invisible Handshake," 52 U. CHI. L. REV. 903 (1985), and Edward Yorio \& Steve Thel, The Promissory Basis of Section 90, 101 YALE L.J. 111 (1991), purported to find from their reading of section 90 cases that courts were not taking seriously the inquiry into reliance and that results in section 90 cases turned solely upon the type of promise and the context within which it was made. See Farber \& Matheson, supra, at 904-05 (surveying over 200 promissory estoppel cases from 1975 to 1985 and asserting that, in spite of the continued use of the "language of reliance," courts had developed a new rule whereby "any promise made in furtherance of an economic activity is enforceable"); Yorio \& Thel, supra, at 113 (arguing that, in section 90 cases, "[a] promise will be fully enforced ... if the promise is proven convincingly and is likely to have been serious and well considered when it was made"). More recent case commentators, however, have concluded that courts still insist upon proof of "definite and substantial" reliance before awarding recovery on a promissory estoppel theory. See Sidney W. DeLong, The New Requirement of Enforcement Reliance in Commercial Promissory Estoppel: Section 90 as Catch-22, 1997 WIS. L. REV. 943, 948 (analyzing all reported promissory estoppel cases in 1995 and 1996 and concluding that "[c] ontemporary courts rigorously enforce Section 90's requirement that the promise induce actual reliance by the promisee"); Robert A. Hillman, Questioning the "New Consensus" on Promissory Estoppel: An Empirical and Theoretical Study, 98 COLUM. L. REv. 580, 582-83, 582 n.15 (1998) (reviewing 362 federal and state cases between 1994 and 1996 and noting "the crucial role reliance plays in courts' decisions either to deny or affirm a promissory estoppel claim at a preliminary motion or final judgment stage of a litigation"). 
documents to the effect that they did not intend to be bound until the execution of a final written contract, courts will find (often as a matter of law) that there was no contract. Having incurred potentially large expenses in what it says was reliance upon various assurances made by the faithless suitor, the disappointed party seeks recovery of at least its reliance expenses on a promissory estoppel theory.

For generations of contracts scholars and students, the case of Hoffman v. Red Owl Stores, Inc. ${ }^{40}$ has made the argument in favor of allowing recovery on a promissory estoppel theory in such a case. In Hoffman, an innocent, inexperienced rural baker was enticed to do a whole series of costly and difficult things-selling his bakery, buying and then selling a grocery store, obtaining an option on a piece of land-by a sophisticated, big-city franchisor's repeated promises and assurances that, if the baker only did one more such thing, then he would become one of their franchisees. ${ }^{41}$ The franchisor did not grant Mr. Hoffman the franchise, and he was left in a far worse position than he had been in before he met with Red Owl. Such a case seems to epitomize the intuitive case for promissory-estoppel-based liability for precontractual negotiations: There was nothing good about what the franchisor did, no reason for it to repeatedly promise a franchise to Mr. Hoffman-the franchisor was simply a bad actor who either negligently or intentionally (but for unknown reasons) inefficiently induced reliance.

Now this story relies an awful lot on sympathy for Mr. Hoffman, the unsophisticated rural baker duped into a veritable reliance free fall. One would perhaps have predicted that the first thing hardhearted economic analysts would do when they turned to analyze Hoffman would have been to try to explain why the case was wrong, why liability was not after all appropriate. For whatever reason, this is not what occurred. Instead, economic analysts of contract law came to view Hoffman as exemplifying the other side of the reliance problem: the specter of inefficient underreliance. ${ }^{42}$ This problem can be seen most directly by supposing that the law did not award any remedy

133 N.W.2d 267 (Wis. 1965).

${ }^{41} I d$. at 268-71.

42 For classic statements with regard to this argument, see Craswell, supra note 17, at 489-95 (emphasizing the extent to which Red Owl might have benefited had the contract been formed); Avery Katz, When Should an Offer Stick?: The Economics of Promissory Estoppel in Preliminary Negotiations, 105 YALE L.J. 1249, 1270-77 (1996) (addressing the "incentive problem"). 
for breach. As explained earlier, just as people overinvest in reliance upon contractual promises when the law fully compensates them in the event of breach regardless of their level of reliance, ${ }^{43}$ so, too, would they underinvest in reliance upon promises if the law did not compensate their losses (or compensated them too meagerly) in the event of breach. While there may not have been a formal contract in Hoffman, it is easy to imagine that the value of the franchise-if one had been awarded-would have been greater by virtue of Mr. Hoffman's precontractual reliance expenditures. If this is so, then Mr. Hoffman's reliance may well have been efficient. But a person will not incur such early reliance expenditures if she later can be held up by another party who blithely claims that, since there was no contract when the reliance expenditures were incurred, it therefore has no obligation to pay for any of those expenditures, or even to finish the negotiations, thus inducing the relying party to agree to terms that mean a net loss for her.

This problem is known in the economic theory of contracts as a contractual "holdup problem." ${ }^{44}$ There are a variety of potential solutions to the holdup problem. ${ }^{45}$ One is for the law to compensate some, but not all, of such early (or precontractual) reliance-some, to give the promisee an incentive to incur efficiently early reliance costs, but not all, lest the promisee incur reliance costs that are inefficiently large. First set out by Richard Craswell ${ }^{46}$ and Avery Katz, ${ }^{47}$ this solution to the "precontractual reliance" problem was refined and extended by Lucian Bebchuk and Ben-Shahar, ${ }^{48}$ who demonstrated formally (that

${ }^{43}$ See supra text accompanying notes 21-28 (addressing the conditions that breed overreliance).

${ }^{44}$ Ben-Shahar, for example, describes the problem as follows: "The holdup problem arises when parties cannot contract over reliance expenditures due to high transaction costs, non-verifiability of the investment, and strategic considerations." BenShahar, supra note 1, at 1848 n.37.

${ }^{45}$ For a useful survey and explanation of such possible solutions, see Edlin, supra note 11 , at $176-78$

${ }^{46}$ See Craswell, supra note 17, at 495-97 (arguing that courts will often find a commitment binding one party to a failed negotiation when reliance by the other party would have been efficient).

${ }^{47}$ See Katz, supra note 42 (illustrating a "regulatory approach" to promissory estoppel).

${ }^{48}$ Lucian Arye Bebchuk \& Omri Ben-Shahar, Precontractual Reliance, 30 J. LEGAL STUD. 423 (2001). 
is, mathematically) that various kinds of intermediate liability rules will optimally calibrate such reliance expenditures. ${ }^{49}$

\section{THE MODEL OF RELIANCE: ITS EMBODIMENT IN A "NO-RETRACTION" PRINCIPLE THAT CREATES MORE RELIANCE PROBLEMS THAN IT SOLVES}

It is this latter model that provides the basis for the efficiency arguments Ben-Shahar presents in favor of his no-retraction principle. ${ }^{50}$ In Ben-Shahar's no-retraction regime, a disappointed relying party can always threaten credibly to impose liability for her reliance damages upon a faithless suitor who walks away from the negotiations following the reliance. ${ }^{51}$ The temptation for a faithless suitor to allow or even encourage such reliance by promising to pay for it (either directly or through a sufficiently high price proposal) and then reneging on the promise disappears because the disappointed relying party can always do better by suing for her reliance costs (under the contract as originally proposed by the faithless party) than by agreeing to the holdup. Rather than bearing the entire reliance cost-which he would do if he tried to hold up the relying party, who would sue and get back her entire reliance expenditure-the faithless suitor is better off staying with the negotiations and agreeing to a price that effectively shares the reliance investment between the parties. The noretraction regime thus eliminates, says Ben-Shahar, the specter that parties will refuse to incur efficient early reliance expenses, lest they be held up afterward by faithless suitors who refuse to share those expenses. $^{52}$

The no-retraction regime does indeed protect early reliance expenditures, but it raises an even more serious problem, one that economists have not worried about because it does not exist under the existing doctrinal structure governing liability for precontractual reliance. The problem is that (as Ben-Shahar's title clearly indicates), under the no-retraction regime, a party can foist a legal obligation to reimburse its reliance expenses upon any other party simply by incurring those expenses. This threat, in turn, will often lead the victim of

${ }^{49} I d$. at $456-57$.

${ }^{50}$ See Ben-Shahar, supra note 1, at 1847-53 (outlining the efficiency-based implications of his no-retraction principle).

${ }^{51} I d$. at 1849.

${ }^{52} I d$. at $1849-50,1849 \mathrm{nn} .39-40$. 
such unwanted reliance to contract with the relying party even when it is inefficient for her to do so. Suppose, for instance, that a really productive employee can, by spending a mere $\$ 20$, generate $\$ 100$ in value for a firm (for a net increase of $\$ 80$ ), while an unproductive employee can generate the same $\$ 100$ value only by spending $\$ 95$ (for a net increase of $\$ 5$ ). Efficiency obviously requires that the employer hire the productive employee. Under the no-retraction regime, however, once the unproductive employee has made her $\$ 95$ investment, the employer is better off sticking with that employee and sharing that employee's reliance costs and the value that such costs have generated than she would be by contracting with the productive employee and reimbursing the unproductive employee's $\$ 95$ reliance cost. The reason is that, under the no-retraction regime, the employer must pay the inefficient employee's $\$ 95$ reliance expense regardless of whether she "retracts" and so cannot be made better off by retracting and going with the more efficient employee. Crucially, such inefficiency arises only because the inefficient $\$ 95$ reliance expenditure has already been incurred. (If it had not been spent, then even if the employer had a contract with the inefficient employee, she could bargain with that employee, sharing the gains from efficient breach to get the employee's consent to such breach.) Any regime that insures early reliance, as does the no-retraction regime, creates a profound disincentive to efficient breach.

Ben-Shahar seems to be unaware of this problem. He does discuss what he calls the "[u]nwanted $[\mathrm{t}]$ ransactions" problem, ${ }^{53}$ but what he means by this is not transactions that are intentionally and strategically foisted upon people by virtue of early unwanted reliance, but rather, the problem that compensating the reliance expenses incurred by an initial, potential contracting partner may often create a disincentive to switching partners when a better (net-value-increasing) partner somehow materializes. ${ }^{54}$ What he says about his problem is not particularly persuasive, but what he does not even address-the problem of strategic use of early reliance to force parties into inefficient transactionsis much more serious.

This problem is far from fanciful. Indeed, from my own reading of cases involving the application of promissory estoppel to the preliminary negotiation or precontractual context, my impression is that

\footnotetext{
${ }^{53}$ Id. at $1852-53$.

${ }^{54} I d$. at 1852.
} 
the reason why businesspeople incur substantial reliance expenses before they have reached agreement is not because they are naïve about contract law and think that they really do have a legally enforceable agreement, but because they know that they do not yet have a deal and are fearful that the other party will soon do the deal with someone else. Such businesspeople incur premature reliance expenses for two reasons: first, to pressure the other party into thinking that it will indeed incur potential contractual liability if it doesn't agree to go ahead with the prematurely relying party and, second, to persuade the other party that they really can do the job (on the seller's side) or come up with the necessary financing (on the buyer's side).$^{55}$ The presence of such interactions even under the existing doctrinal setup governing precontractual liability strongly suggests that Ben-Shahar's no-retraction regime would induce precisely the kind of behavior that centuries of common law judges have been worried about in fashioning rules designed to discourage the "officious intermeddler" who is so well known in the law of restitution. ${ }^{56}$

In my view, the effect of Ben-Shahar's proposal in encouraging such inefficient intermeddling is likely to swamp whatever efficiency benefits it might have in encouraging early reliance. In my ongoing reading of the cases involving the application of promissory estoppel in preliminary negotiations, I have seen very few in which it seems that early reliance-reliance before agreement had been reached-was necessary to increase the value of the deal. Instead, parties seem to make premature reliance investments for precisely the sort of strategic reasons discussed above. ${ }^{57}$ Moreover, there are many cases in which the only reliance expense claimed by the plaintiff is its cost of trying to

${ }^{55}$ For an example of a case involving the second line of reasoning, see GSGSB, Inc. v. New York Yankees, 862 F. Supp. 1160, 1162 (S.D.N.Y. 1994) (describing a dispute in which the plaintiff architectural firm performed preliminary work and sought financing in order to secure a contract with the defendants), aff'd, Nos. 95-9272, 96-9202, 1997 U.S. App. LEXIS 17433 (2d Cir. July 9, 1997).

${ }^{56}$ For one discussion of the "officious intermeddler," see Saul Levmore, Explaining Restitution, 71 VA. L. REV. 65, 65 (1985) ("The rule is, of course, that . . 'officious intermeddlers' do not recover in restitution even if they can prove their expenses or the value of their provisions.”).

${ }^{57}$ See, e.g., Walser v. Toyota Motor Sales, U.S.A., Inc., 43 F.3d 396, 402 (8th Cir. 1994) (affirming the district court's limitation on the damages available to a prospective car dealer in part because there was only a very short period of time during which the prospective dealer could have relied as he had been quickly told that the deal had turned sour); Doll v. Grand Union Co., 925 F.2d 1363, 1365 (11th Cir. 1991) (finding no liability where developers obtained options on land for a supermarket project with only a preliminary "indication of interest" from the anchor tenant). 
negotiate the failed deal. ${ }^{58}$ While the cases do present situations in which a bargainer relies even though it clearly knows that an agreement has not yet been reached, the cases do not seem to me to describe situations in which it was efficient for bargainers to rely at such an early stage in the bargaining process. This is to say that the cases do not present situations involving the potential for the kind of holdup problem that Ben-Shahar's no-retraction regime is designed to address. One suspects that a primary reason why the cases don't display the holdup problem is because, whenever early reliance investment really is valuable, the party making that investment does not actually do so until she gets an agreement allocating the cost of that investment and insuring her of some return on it. From my read of the cases, innocents like Mr. Hoffman, who incur big reliance costs without any agreement regarding the allocation of those costs, are rare. Indeed, one must wonder whether Mr. Hoffman was not in fact so innocent, whether he might well have been a strategic, prematurereliance investor who just happened to lose his bet. ${ }^{59}$

\section{MODELS OF INVESTMENT VERSUS MODELS OF INFORMATION: UNDERSTANDING THE REAL PROBLEM POSED BY PRECONTRACTUAL LIABILITY}

In response to my article, Communication and Courtship: Cheap Talk Economics and the Law of Contract Formation, ${ }^{60}$ that was published a couple of years before the publication of their joint work, Bebchuk and Ben-Shahar defended, ${ }^{61}$ and Ben-Shahar now again defends, ${ }^{62}$ the

58 See, e.g., Budget Mktg., Inc. v. Centronics Corp., 979 F.2d 1333, 1334 (8th Cir. 1992) (affirming the district court's decision that any reliance that may have been incurred was not reasonably incurred); see also Budget Mktg., Inc. v. Centronics Corp., 927 F.2d 421, 427-28 (8th Cir. 1991) (remanding the case for further consideration of a claim for various negotiation expenses based on the promissory estoppel theory).

${ }^{59}$ This conjecture is supported by Mr. Hoffman's relative success in the business world. After the Hoffman case concluded, Mr. Hoffman got a job as a salesman for the Metropolitan Life Insurance Company where, after winning honors for achieving the highest sales, he was promoted to the position of District Manager for Milwaukee. 1 STEWART MACAULAY ET AL., CONTRACTS: LAW IN ACTION, 403-04 (2d ed. 2003).

${ }^{60}$ Johnston, supra note 13.

${ }^{61}$ See Bebchuk \& Ben-Shahar, supra note 48, at 452 (dispelling the "common view ... that imposing liability for precontractual reliance will discourage parties from entering negotiations").

${ }^{62}$ See Ben-Shahar, supra note 1 , at 1850-52 (recognizing and responding to the claim that parties would be discouraged from entering negotiations or establishing precontractual understandings with a no-retraction regime). 
no-retraction liability regime against the general objection that their regime creates an inefficient disincentive for parties to enter negotiations in the first place. That the no-retraction regime has the potential to do so is intuitively obvious, for under that regime, terminating negotiations almost automatically results in liability for the disappointed party's negotiating expenses. In Contracts Without Consent, however, Ben-Shahar confidently concludes (and demonstrates with a numerical example) ${ }^{63}$ that the no-retraction regime "will unambiguously lead the parties to enter into negotiations in more cases in which there is a potential surplus than they would in the absence of liability." ${ }^{64}$

This statement is true. When the parties enter negotiations already knowing that there are mutually beneficial gains from trade to be had and that those gains will be increased by early reliance, the no-retraction regime-by eliminating the holdup problem that would eliminate the incentive to make such early reliance investmentsmakes such negotiations more profitable. But this admittedly true result is largely irrelevant to the class of problems that judges deal with when they have to decide whether the parties reached agreement before one of them walked away from a negotiation. Whether one calls it "precontractual negotiation" or "dealmaking," the kinds of transactional negotiations that have generated the body of case law answering the question "when do the parties become legally bound?" do not involve negotiations over known gains from trade, but whether gains from trade exist in the first place. ${ }^{65}$ When negotiating over the division of a pie, parties face conflicting interests. When deciding whether to invest to increase the size of the pie before those negotiations have even concluded (the holdup specter), the parties' interests conflict even more sharply, for the relying party can actually be made worse off, while the other party can be made very well off indeed. When negotiating to determine whether to do a transaction, however, the parties do not generally begin knowing that the deal will work. Rather,

${ }^{63}$ Id. at 1849 nn.39-40, 1851 n.45.

${ }^{64}$ Id. at 1851 .

${ }^{65}$ I cannot provide here a catalogue of cases supporting this assertion, but cases such as R.G. Group, Inc. v. Horn E Hardart Co., 751 F.2d 69, 72-74 (2d Cir. 1984), in which a deal fell apart because the parties could not agree on the territorial extent of the fast food franchise being negotiated, are typical. In such cases, the failure of the parties to agree upon a key term signals that there may have been no agreement on that term, and hence no deal, which would have made them both better off relative to the status quo. 
their first problem is to determine whether there is a "pie"-a "cooperative surplus," in the language of game theory-for them to worry about dividing.

In these circumstances, when the parties are negotiating to determine whether gains from trade exist, rather than how to split known gains, their interests are often not conflicting, but shared. In such a negotiating context, reliance expenditures are not made to increase the value of the transaction, but to gain information as to whether a mutually beneficial transaction can be somehow arranged. The relevant question regarding potential legal liability in the event that such negotiations fail to culminate in an executed transaction is not whether such liability can create incentives for optimal early reliance, but rather, whether such liability improves or harms incentives for information transmission, whether such liability makes it easier or harder for the parties to determine whether there are gains from trade to be had, and whether the prospect of potential legal liability causes the market for potential transactions to become bigger or smaller.

In my above-referenced article, Communication and Courtship, ${ }^{66} \mathrm{I}$ used some ideas from non-cooperative game theory to develop a framework for answering these questions. That framework rests upon the game-theoretic distinction between costly signals and cheap talk. ${ }^{67}$ When a person sends a costly signal—such as by achieving a college degree-the signal may send information to other market participants-such as that the person is talented and will have high labor market productivity-but regardless of whether it communicates such information, sending the signal imposes a direct cost on the senderin the example, the opportunity and direct costs of college. Even though it may communicate information to the market, contrasting cheap talk has no direct cost. It costs nothing, for example, for a recent college graduate to say that she is "incredibly enthusiastic" about a particular job opening with a potential employer with whom she is already speaking. By the same token, one may well suspect that such cheap talk is not likely to convey any real information to the employer. After all, wouldn't every jobless, job-hungry, recent college graduate in a tight job market have said that she was "incredibly enthusiastic" about the job opening?

\footnotetext{
${ }^{66}$ Johnston, supra note 13.

${ }^{67}$ For more detail on this distinction than I have space to provide below, see $i d$. at 404-39.
} 
This question may seem virtually rhetorical, logically requiring a "yes" answer. Such an answer is not, however, necessarily the correct one. Underlying the idea that costless talk can never be informative is an intuition about the strategic context in which such talk occurs. This intuition has two parts: a feeling, first, that parties who are bargaining or negotiating, or are even talking about bargaining or negotiating, are likely to be adversaries engaged in a game with conflicting, rather than corresponding, interests and, second, that, when there are several actors on each side of the discussions-lots of potential buyers and sellers, for example-they all have the same interests. For ease of reference, I will call these the assumptions of "conflicting interests across sides of the market" and "shared interests within the sides of the market." If it seems obvious that all the recent college graduates in my hypothetical will want to say that they are "incredibly enthusiastic" about the job opening, then it is only because we are implicitly supposing that, although the employer wants to hire the best-qualified applicant for the lowest possible salary, every recent graduate wants the job, regardless of whether or not she is qualified, and at the highest possible salary. In this implicit scenario, the applicants are all the same-they all desperately need and want this job-but their interests are opposed to those of the employer. Because all such applicants will say that they are "incredibly enthusiastic" about the job, the statement "I am incredibly enthusiastic" does not convey any information about the particular applicant's type (that is, about whether she is or is not well qualified for the particular position).

Not every situation involving cheap talk involves such conflicting interests across sides of the market or shared interests within each side of the market. Indeed, even in this simple example, we may think it unlikely that all the recent college graduates really want this particular job. Someone who is grossly underqualified for this offered position may be better off simply telling the prospective employer that she is not interested, rather than expressing interest and then going through a costly and time-consuming interview process that will eventually lead to her rejection anyway. Employers are not likely to be identical either. An employer seeking a position suitable for a person with relatively little experience may not want to hire someone who is overqualified and who will be disenchanted and unproductive if underemployed. Such variation within each side of the market radically transforms the strategic incentives for cheap talk communication. Relatively highly qualified job candidates may declare that they are "not interested" in lower-echelon jobs in which less qualified job 
candidates say that they are "incredibly interested." Similarly, highly qualified candidates may say that they are "incredibly interested" in jobs requiring a high level of skill and experience, while less qualified candidates state that they are "not interested" in such jobs.

The lesson from this simple example is in fact very general: When there are at least some shared interests across the market (something that is very likely to be true when there are divergent interests within each side of the market), transactional cheap talk can be credible and informative. To see how this lesson applies to help us understand whether potential legal liability encourages or discourages parties from communicating socially valuable information by making promises, observe that "promises" are just a species of linguistic convention used to convey present intentions about future actions. Assuming away social or other nonlegal sanctions, if the law does not impose liability for the failure to keep a promise, then a promise is just another kind of cheap talk. By imposing liability for broken promises, the law can convert what would otherwise be cheap talk into a costly signal. If what one is concerned about is creating incentives for informative promising, then the question is whether promises are likely to be informative even when they are cheap talk.

In my article referenced above, I demonstrate not only that there are general situations in which promissory statements are likely to be informative when they are cheap talk, but also that, in those situations, promises are likely to be informative only if they are cheap talk. ${ }^{68}$ In other words, it is sometimes true that a promissory statement will be informative only if there is no liability in the event that the promised action is not forthcoming. Loosely speaking, the situations in which informative promising depends upon the freedom from potential contractual liability arise early in the dealmaking process, when communications are being sent to and from a large number of heterogeneous buyers and sellers. In such situations, buyers and sellers share an interest across the market in minimizing the transaction costs of failed dealmaking by attracting and continuing to talk only to those market actors on the other side of the market with whom they have a reasonable chance of ultimately transacting. Market pessimists can convey pessimism quite easily without risking legal liability. It is, after

\footnotetext{
${ }^{68}$ See id. at 412 (“[T] he informativeness of precontractual talk may depend upon the fact that it is cheap talk ...."); see also text accompanying notes 60, 66 (providing further background about this article's place in the debate at hand as well as its substantive arguments).
} 
all, quite easy to sound gloomy about the prospect of ever transacting with someone. Market optimists, however, may quite naturally use promissory language like "we've got a deal" or "everything looks ready to go" when all they mean to say is that a deal is very likely, relatively speaking. Understood as statements regarding the ultimate probability of a deal, such statements may be perfectly truthful. Especially at early stages of the dealmaking process, "very likely" does not mean "certain." At such stages, a party's optimistic, promissory statements may be completely informative and truthful and yet be perfectly consistent with the failure ultimately to transact. Crucially, were liability imposed every time such an early optimistic assurance was not followed eventually by a successful transaction, the incentive to send such optimistic assurances would often be eliminated. (More precisely, it would be eliminated in those cases in which there is a relatively high probability of not ultimately transacting - cases in which the elimination of incentives for optimistic talk is actually most likely to cause market pessimists to withdraw from the market entirely.)

This same analysis shows that, later in the bargaining process, when the number of parties has been winnowed down to one or only a few on each side of the transactional divide, liability for optimistic, promissory statements is likely to enhance, rather than destroy, incentives for informative communication. Early-stage cheap talk allows parties the freedom to discover whether or not there are indeed likely gains from trade. Late-stage communication affects primarily the magnitude and distribution of the gains from trade. At such late stages-roughly corresponding to the classic "offer-counteroffer" pattern of give-and-take negotiations — $^{69}$-statements such as "ask" and "offer" prices will be informative only if they are legally binding (that is, only if they are not cheap talk, but rather, costly signals of future intent).

The prescriptions generated by this analysis for when promising should be cheap and when it should be costly closely track the doctrinal line that common law judges have drawn between contract and no contract. ${ }^{70}$ As best illustrated by the modern test for when

\footnotetext{
${ }^{69}$ For a discussion about this pattern, see Johnston, supra note 13, at 442-55, 49799.

${ }^{70}$ See id. at 439-83 (elucidating contractual theory through the analysis of a number of cases).
} 
agreement is reached in complex business transactions, ${ }^{71}$ common law judges have, on my analysis, been very sensitive to the strategic structure of dealmaking and have understood that, while it is important that promising remain cheap early in the dealmaking process, it is equally important that it be costly later in the process. Cases that seem to create exceptions to this doctrinal pattern-such as the decision in Teachers Insurance $\mathcal{E}$ Annuity Ass'n of America v. Tribune Co., ${ }^{72}$ holding that a commercial loan commitment letter constituted a binding preliminary agreement ${ }^{73}$-are in fact perfectly consistent with this pattern. By enforcing explicit agreements to alter the doctrinal line between agreement and no agreement, these cases merely affirm that the doctrinal line is indeed a contract default rule that the parties may shift by mutual assent.

Judicial decisions involving the application of promissory estoppel, by contrast, have tended to create an economically unjustified risk of legal liability for early-stage promising. They have done so by giving a dealmaking party the ability to constrain the other party's options by unilaterally deciding to incur reliance expenditures. When negotiations start out on an optimistic note but begin to sour, the disappointed party may be well aware that it is about to lose a hoped-for market opportunity. If the disappointed party relies, however, the other party's (the promisor's) options are now constrained: It must either go ahead with the deal or walk away and face the prospect of reliance-based liability. While it is true that the better decisions involving the application of promissory estoppel to the dealmaking context do allow a promisor to escape liability by, in effect, discouraging such early-stage reliance, ${ }^{74}$ there is no need for such doctrinal complexity. The better and simpler approach is for courts to make promise liability turn upon the doctrinal determination of whether or not the parties had or had not yet reached agreement, an approach which draws a relatively clear line between liability-free, early-stage promissory talk and liability-triggering, late-stage promissory talk. That line, after all, is a default line, and if the parties do not find it in their joint interest to postpone liability, they can and do explicitly say so.

${ }^{71}$ This test is set out in R.G. Group, Inc. v. Horn $\mathcal{E}$ Hardart Co., 751 F.2d 69, 74-77 (2d Cir. 1984).

${ }^{72} 670$ F. Supp. 491 (S.D.N.Y. 1987).

${ }^{73}$ Id. at 499.

${ }^{74}$ This possibility was suggested by Marilyn Miglin, Inc. v. Gottex Industries, $790 \mathrm{~F}$. Supp. 1245, 1250-51 (S.D.N.Y. 1992). 
Thus, on my analysis, while the courts have perhaps been a bit too hospitable toward precontractual liability claims based on a theory of promissory estoppel, they have developed a body of doctrine that draws a line between the early "no agreement/no liability" stages and the late "agreement/liability" stages in transactional negotiation that tends to accord strikingly well with what is economically efficient. On my view of the world, the simple dichotomy between agreement and no agreement that courts rely upon in determining when a negotiating party's promissory statements begin to trigger potential liability if they are not fulfilled is not only much simpler, but also much more economically sound, than is the admittedly creative, but ultimately disastrous, no-retraction regime suggested by Professor Ben-Shahar. 